\title{
FLOW konference: TV a radio studies v Olomouci
}

\author{
Andrea Hanáčková
}

FLOW konference 02. Radio a TV studies v Čechách a na Slovensku. Nové formáty a možnosti konvergence televizního a rozhlasového média. 18.-19. září 2015, Univerzita Palackého Olomouc.

Když v roce 1978 napsal Bruce Woolley s kamarády písničku o tom, že video zabilo rozhlasové hvězdy („Video Killed the Radio Star“), pojmenoval tím stále rostoucí vliv audiovizuálních médií, před nimiž rádio od poloviny padesátých let dvacátého století jen bezmocně couvalo do pozadí. Když pánové Peace a Dennis hledali o dalších dvacet let později průrazný titul své knížky o rádiu, zvolili pro něj přízvisko „zapomenuté médium“ („Radio: The forgotten medium“, 1995). Tou dobou už ale byly zformovány skupiny akademiků na univerzitách všude po světě a etabloval se obor radio studies, který v českém jazyce nemá přesný ekvivalent, nejpříhodněji ho lze překládat jako rozhlasová studia, což je značně nepřesné. Existence samotného oboru každopádně odráží skutečnost, že auditivní vnímání světa je člověku stejně přirozené jako to audiovizuální, že velké množství lidí stále rádio ke svému životu potřebuje a že zároveň existuje dostatečná skupina akademiků ochotných o něm přemýšlet, vydávat o něm knihy a diskutovat na konferencích.

Zhruba o desetiletí dříve začaly vycházet knihy i o zásadním kulturním vlivu televizního vysílání. Zatímco v předchozích desetiletích byla televize vnímána spíše jako symptom aktuálních společenských neduhů, na sklonku 20. století se stala klíčovým dodavatelem příběhů a informací, aktivně přítomným $\mathrm{v}$ západních domácnostech už celou třetinu dne. Masové rozšíření notebooků, tabletů a mobilních telefonů, jejichž prostřednictvím dnes řada diváků televizní obsahy konzumuje, tento podíl ještě výrazně zvyšuje. Je tedy zjevné, že televizí jako fenoménem je nutné se zabývat, pokud chceme porozumět tomu, jaké příběhy většinovou společnost zajímají, jakou prezentaci světa tato společnost bere za svou a jakým způsobem se v něm prostřednictvím televizního média orientuje. Pozornost vůči televizi napříč generacemi zvyšuje i skutečnost, že se k ní - jako k pružnému médiu - uchylují špičkoví tvưrci a že se v ní díky tomu dynamicky rozvíjejí nové formáty.

Zcela v logice historických událostí přichází nyní - po dalších dvaceti letech - TV a radio studies i do České republiky. Nejčastěji jako „přívěsek“ k jiným oborům, které mají v názvu kulturální studia, medialitu, žurnalistiku, sociální vědy. Samostatný obor TV a radio studies ostatně nenajdete ani na západních univerzitách - televize se obvykle vyučuje na katedrách zaměřených na film, rozhlasová témata bývají připojena ke studiu divadla, a to ještě většinou na prakticky orientovaných školách.

Založení nového oboru na olomoucké Univerzitě Palackého je tedy možné chápat jako experiment, který nemá v Evropě žádný precedens a z tohoto hlediska bude zajímavé i trochu napínavé sledovat, jak se obor v českých podmínkách rozvine. Jeho nastavení vychází z přirozených pohnutek - na jednom místě se $\mathrm{v}$ jednom čase 
sešli lidé, které právě tyto dva obory zajímají a kterým chyběla platforma, na níž by mohli budovat relevantní akademické zázemí pro studium televize a rozhlasu. Kromě akreditačních a publikačních snah tedy začínáme $\mathrm{z}$ našeho pohledu logicky pokoušíme se konferenčně propojit všechna pracoviště, která mají k tématu co říci, snažíme se sdělit, že existujeme, usilujeme o to, aby se v Olomouci potkali praktici, kteří obě média denně vytvářejí, s akademiky, již tuto činnost reflektují a teoreticky vymezují.

FLOW konferenci o TV a radio studies jsme v Olomouci uskutečnili již dvakrát v březnu 2013 a v září 2015. Pro obě jsme zvolili interaktivní konferenční formát. Účastníci ve svých příspěvcích preferovali krátké prezentace a diskuze v četných skupinách u kulatých stolů před tradičnějším statickým čtením připraveného referátu. Debaty u „round tables“ probíhaly paralelně na několika místech barokního jezuitského Konviktu, kde sídlí pořadatelská olomoucká Katedra divadelních a filmových studií. Účastníci si tak mohli volit, zda budou diskutovat raději třeba o teoretických aspektech nových formátů s výhledem na parkán a do parku, nebo zda upřednostní například debatu o vývoji audiovizuálních produkcí v éře digitálních technologií pod trámovím zmíněného prostoru. Maximální kvalitu zvukovým i audiovizuálním snímkům zajišţuje útulný filmový sál, ideálním místem setkání u snídaně nebo naopak večerní konferenční párty je podkrovní divadelní sál. Ukázalo se, že až na výjimky lze bez problémů oba obory spojovat a diskutovat o nich současně. $\mathrm{V}$ obou případech jde o metodologicky pluralitní obory, které mají více „bílých“ míst než těch historicky a teoreticky zmapovaných. Reflexe rozhlasového média je na tom přece jen o něco lépe. V Čechách vyšla první obsáhlá publikace A. J. Patzakové Prunich deset let československého rozhlasu už deset let po začátku vysílání (Praha, 1935), za „zlatou éru“, dosud nereflektovanou, lze považovat umělecky i teoreticky hutné období šedesátých let. Komunistický režim však znamenal i pro zkoumání auditivní kultury dvacetiletou pauzu, kterou se dodnes nepodařilo zaplnit. Historie československého rozhlasu má svou reprezentativní přehledovou publikaci Od mikrofonu $k$ posluchačům: Z osmi desetileti Českého rozhlasu (Praha, 2003), která - byt je určena širší veřejnosti - má podstatné náležitosti odborného historického textu. K sepsání podobné publikace historici televize dosud nedokázali spojit síly. Obecně jsou však oba obory v českém kontextu teoreticky hrubě podhodnoceny a zřejmě až s nastupující generací třicátníků a čtyřicátníků může dojít $\mathrm{k}$ průlomu tohoto stavu. Podobně jako rozhlasová studia musí se tedy i studia televizní obracet téměř výhradně na zahraniční zdroje a aplikovat v českém prostoru metodologie a př́stupy formulované v jiných kontextech geografických i společenských. Pětadvacet let po demokratizaci mediálního prostoru však už lze i u nás provádět textuální analýzy z hlediska sémiologických mediálních významů, z hlediska žánrů, narace nebo reprezentace konkrétních sociálních skupin. V rozhlasovém i televizním prostředí se prohlubuje výzkum publika v diváckých a recepčních studiích, jež se kromě tradiční sociologické perspektivy stále intenzivněji soustředí na mechanismy produkce významů samotnými diváky. Pro pochopení fungování mediálního trhu jsou důležité institucionální analýzy, které mají často oporu v analýzách historických. Vzhledem $\mathrm{k}$ tomu, že stále hovoříme nejčastěji o současných médiích, 
bývá proporčně silnou metodou i oral history. Kromě metodologické plurality se v obou oborech uplatňuje i tematická, která zahrnuje jak interpretační studie auditivních a audiovizuálních textů, tak vliv etnografie na diváctví, rozvoj komunitnosti médií, production studies a vývoj technologií, různé formy prezentace a reprezentace, případně vzdělávací roli sledovaných médií. Ostatně ve světě je propojení televize a rádia obvykle mnohem intenzivnější než v Čechách, opatrně diskutované téma možného spojení televizního a rozhlasového média je v jiných zemích již dávno fungující realitou.

Tato a další témata reflektovali hosté, kteří se konference účastnili a především v obou oborech publikují a trvale se výše zmíněnými problémy zabývají. Důležité otázky etických aspektů televizního a rozhlasového vysílání přináší pravidelně jako specifický úhel pohledu etiky a filozofie médií Jan Motal (Fakulta sociální studií Masarykovy univerzity Brno). V září 2015 se zaměřil na vybrané etické aspekty interaktivity jako principu, který je uplatňován v transformaci technologie i obsahu soudobého televizního vysílání z pohledu teorie demokratické kompetence Philippa Bretona. V nových televizních formátech vyznačil akcentovaný narativ úspěchu a konfliktu jako převládající princip, který se $\mathrm{v}$ hraničních podobách mění ve freakshow. Dokázal, jak se negativní vztah těchto jevů odráží v demokratické kompetenci diváků. Postsocialistický kontext zkoumala ve svém příspěvku také Irena Reifová (Fakulta sociálních věd Univerzity Karlovy Praha), která na konkrétním př́kladu seriálu Ošklivka Katka demonstrovala specifika osvojování globálních formátů v reáliích lokální politické historie. K tématu rozšíření konvergentních mediálních praxí v rám- ci českých mediálních publik se v souladu s rozsáhlým kvantitativním šetřením české populace vyjádřil sociolog Jakub Macek (Fakulta sociálních studií Masarykovy univerzity Brno). Následný kvalitativní a etnografický výzkum se soustředí na motivaci výběru konkrétních distribučních kanálo̊ a recepčních rozhraní. $\mathrm{K}$ roli internetu jako platformy nových médií, na kterou se postupně přenáší akcent televizních i rozhlasových vysilatelů se opakovaně vyjadřuje i historik a teoretik televizního vysílání Marek Hlavica (Divadelní fakulta Janáčkovy akademie múzických umění Brno). Nové formáty a žánry jsou aktuální i v rozhlase, jejich praktický aspekt ozřejmili naprŕíklad tvůrci Jiří Slavičínský (Český rozhlas) nebo Tajana Gašparovič (University of Zagreb). Důležitým tématem obou dosavadních FLOW konferencí byla spolupráce praktických médií a akademické obce. Praktici se zájmem naslouchají, jak jsou nejrůznější témata reflektována $\mathrm{v}$ rámci největších a nejdůležitějších konferencí v evropském regionu. TV studia participují na největší regionální konferenci o audiovizuálním umění Screen Industries in East-Central Europe Conference, radio studies mají jako bienále svou Radio Research Conference, kterou pořádá mezinárodní sdružení ECREA (European Communication Research and Education Association). Pro akademiky je naopak velmi cenný pohled na aktivitu dramaturgů, producentů i samotných tvůrců z produkčního zázemí obou médií, vítají možnost nabídnutých stáží. Osvědčil se netradiční konferenční formát novinek a bizarních rozhlasových i televizních experimentů v sekci „What's the buzz" nebo snídaně s tvůrcem zajímavého projektu, který u ranního džusu zábavně popisuje traumatickou produkční zkušenost. Na poslední konferenci takto provedla 
inspirativní exkurzi do tvorby pro děti konzumuje obsah. FLOW konference je a mládež Eva Lammelová, která se podíle- pokusem vykročit k takové reflexi a témala na tvorbě úspěšného vzdělávacího pořadu televize Déčko „Já budu Einsteinem!“.

Když jsem zmínila „zlatou éru“ Československého rozhlasu, měla jsem na mysli nejen samotnou tvorbu, ale především schopnost teoretické reflexe a tvůrčí sebereflexe. V letech 1957-1969 působilo v Československém rozhlase Studijní oddělení. Jeho bohatá publikační, překladová, výzkumná a kritická činnost podporovala vzdělávání rozhlasových pracovníků, přinášela novinky ze zahraniční tvorby i odborné literatury, propagovala médium rozhlasu, vyživovala akademický zájem o konkrétní aspekty rozhlasové tvorby a všestranně je rozvíjela. Po roce 1989 se činnost oddělení nepodařilo natrvalo obnovit, televize se o nic podobného ani nepokusila. Je přitom zjevné, že médiím se v demokratickém zřízení daří dobře, pokud různými způsoby podporují svou reflexi i sebereflexi. A zároveň tehdy, když se aktivně starají o to, co si o nich lidé myslí, nejen o to, kolik jich aktuálně ta současného televizního a rozhlasového média pravidelně nastolovat. Její další ročník se uskuteční v Olomouci v březnu 2017 v podobě mezinárodního setkání akademiků a praktiků v oblasti TV a radio studies.

\section{Bibliografie}

JEŠUTOVÁ, Eva (ed.). 2003. Od mikrofonu $k$ posluchačùm. Z osmi desetileti Českého rozhlasu [From Microphone to Listeners. Digest From the 80 Years of the Czech Radio Broadcasting]. Praha: Český rozhlas, 2003.

KORDA, Jakub. 2014. Úvod do televize 1 [Introduction to Television Broadcasting I]. Olomouc: Univerzita Palackého, 2014.

PATZAKOVÁ, Anna Jarmila. 1935. Prunich deset let československého rozhlasu [The First Ten Years of the Czech Radio Broadcasting Company]. Praha: Radiojournal, 1935.

DOI: 10.5817/TY2016-1-23 